\title{
Emended description of the genus Methylophaga Janvier et al. 1985
}

\author{
Rich Boden \\ School of Biomedical and Biosciences, University of Plymouth, Plymouth PL4 8AA, UK
}

Correspondence

Rich Boden

rich.boden@plymouth.ac.uk
The genus Methylophaga Janvier et al. 1985 comprises eight species with validly published names at the time of writing. The original description of the genus was published over 26 years ago and was based on only two species, namely Methylophaga marina and Methylophaga thalassica - as such, the description of the genus requires updating to take into account the other six known species. Based on literature concerning the eight species of Methylophaga published over the last 26 years, an emended description of the genus is presented, taking into account properties of all members of the species with validly published names.
The genus Methylophaga was designated in 1985 following the isolation of a novel species of halophilic marine methylotrophic gammaproteobacteria, named Methylophaga marina, and the reclassification of 'Methylomonas thalassica' as Methylophaga thalassica (Janvier et al., 1985). The description of the genus was based on a number of strains of the only two species then known, and indicates that all members of the genus are 'auxotrophic for $\mathrm{B}_{12}$ ' and 'isolated from marine environments'. Following the description to date of a further six Methylophaga species with validly published names, namely $M$. alcalica (Doronina et al., 2003a), $M$. aminisulfidivorans (Kim et al., 2007), M. lonarensis (Antony et al., 2012), M. muralis (Doronina et al., 2005, 2011), M. sulfidovorans (de Zwart et al., 1996, 1998) and M. thiooxydans (Boden et al., 2010, 2011), along with the isolation of further strains of M. marina that do not require vitamin $\mathrm{B}_{12}$ ( Li et al., 2007), it is clear that the description of the genus requires updating to bring it in line with present knowledge of the genus. A number of other strains have been designated species of the genus Methylophaga, namely ' $M$. limanica' (Doronina et al., 1997) and 'M. natronica' (also known as ' $M$. buryatica'; Doronina et al., 2003b), although these names have not been validly published and the strains are therefore not included in the updated description. Genome sequences are now available for M. aminisulfidivorans (Han et al., 2011) and M. thiooxydans (Boden et al., 2011), and will assist in further characterization of members of this genus.

The phylogenetic positions, with respect to 16S rRNA gene sequences, of the eight Methylophaga species with validly published names are shown in Fig. 1. It can be seen that the three alkaliphilic species, M. alcalica, M. lonarensis and $M$. muralis, form a distinct clade away from that containing the type species (M. marina) - this is consistent with the relatively low identities of these sequences to that of the type species, as shown in Table 1. Additionally, the DNA $\mathrm{G}+\mathrm{C}$ contents of $M$. alcalica and $M$. lonarensis are the highest within the genus (see Table 1), although that of $M$. muralis is more similar to those of non-alkaliphilic species. Further studies into the chemotaxonomic properties of the three alkaliphilic Methylophaga species, along with DNADNA hybridization against $M$. marina, are required to verify their position, although, for the sake of this emendation, they are included in the genus Methylophaga.

Differential physiological and chemotaxonomic properties are given in Table 2. It can be seen that the predominant cellular fatty acids have only been determined in half of the species, although palmitic $\left(\mathrm{C}_{16: 0}\right)$ and palmitoleic $\left(\mathrm{C}_{16: 1}\right)$ acids are found in all species analysed and vaccenic acid $\left(\mathrm{C}_{18: 1 \omega 7 c}\right)$ predominates in all of the alkaliphilic species; it is also present at low levels (2.3\%) in M. aminisulfidivorans (Kim et al., 2007). Dominant cellular phospholipids are phosphatidylethanolamine and phosphatidylglycerol in those species analysed (M. alcalica, M. aminisulfidivorans, $M$. lonarensis and M. muralis; references in Table 2). Given that these parameters have not been determined for the type species, they are not included in the emended description, but are included here for completeness. In terms of substrate ranges, $M$. lonarensis appears to be the most restricted, growing only on methanol, which is a substrate common to all members of the genus, although the majority also grow on monomethylamine and fructose (as shown in Table 2). M. aminisulfidivorans, M. sulfidovorans and $M$. thiooxydans also grow on dimethylsulfide, with the latter two species exhibiting chemolithoheterotrophy at the expense of sulfide and thiosulfate, respectively (de Zwart et al., 1996; Boden et al., 2010). Fructose is the most commonly used multicarbon compound, although substituted thiophenes and higher alkanesulfonates can be used by some species, albeit slowly (Boden et al., 2011).

It is clear that many species have properties that conflict with the description as given by Janvier et al. (1985) 


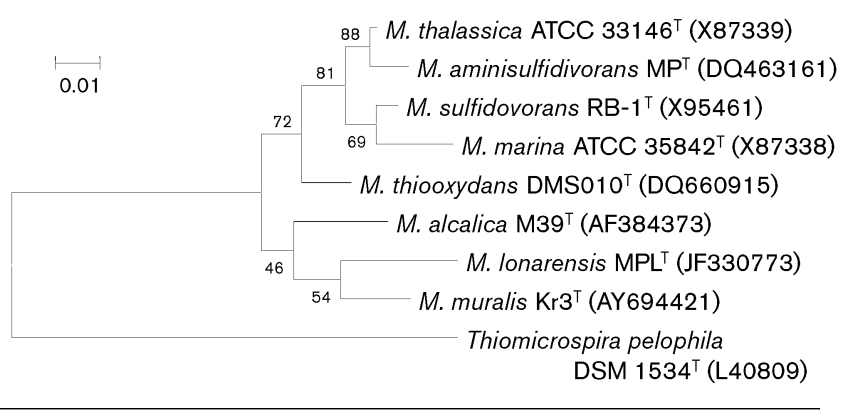

Fig. 1. Maximum-likelihood tree showing the phylogenetic positions of members of the genus Methylophaga based on 1366 nt of the 16S rRNA gene sequences, using the Tamura-Nei model. Bootstrap values (\%) are given from 500 replicates. Bar, 1 difference per hundred. GenBank accession numbers are given in parentheses.

- namely with respect to $B_{12}$ auxotrophy, alkaliphilicity and physiological properties. To rectify conflicts and to bring the description into line with information about Methylophaga species gained over the last 26 years, the following emended description of the genus is proposed, taking into account the properties of all eight species with validly published names to date.

Table 1. Differential molecular properties of type strains of the eight currently recognized species of the genus Methylophaga

\begin{tabular}{|c|c|c|c|c|}
\hline $\begin{array}{l}\text { Methylophaga } \\
\text { species }\end{array}$ & $\begin{array}{l}\text { Type } \\
\text { strain }\end{array}$ & $\begin{array}{c}\text { DNA } \\
\text { G+C } \\
\text { content } \\
(\mathrm{mol} \%)\end{array}$ & $\begin{array}{l}\text { 16S rRNA } \\
\text { gene } \\
\text { identity } \\
(\%) \text { to } \\
\text { M. marina }\end{array}$ & Reference \\
\hline M. alcalica & $\mathrm{M} 39^{\mathrm{T}}$ & 48.3 & 94 & $\begin{array}{l}\text { Doronina } \\
\text { et al. }(2003 a)\end{array}$ \\
\hline M. aminisulfidivorans & $\mathrm{MP}^{\mathrm{T}}$ & 44.9 & 96 & $\begin{array}{l}\text { Kim et al. } \\
(2007)\end{array}$ \\
\hline M. lonarensis & $\mathrm{MPL}^{\mathrm{T}}$ & 50.0 & 94 & $\begin{array}{l}\text { Antony et al. } \\
\text { (2012) }\end{array}$ \\
\hline M. marina & $222^{\mathrm{T}}$ & 43.0 & 100 & $\begin{array}{c}\text { Janvier et al. } \\
\text { (1985) }\end{array}$ \\
\hline M. muralis* & $\mathrm{Kr} 3^{\mathrm{T}}$ & 44.6 & 93 & $\begin{array}{l}\text { Doronina } \\
\text { et al. }(2005)\end{array}$ \\
\hline M. sulfidovorans & $\mathrm{RB}-1^{\mathrm{T}}$ & 42.4 & 97 & $\begin{array}{l}\text { de Zwart } \\
\text { et al. (1996) }\end{array}$ \\
\hline M. thalassica $\dagger$ & $\begin{array}{l}\text { ATCC } \\
34146^{\mathrm{T}}\end{array}$ & 44.0 & 97 & $\begin{array}{c}\text { Janvier et al. } \\
\text { (1985) }\end{array}$ \\
\hline M. thiooxydans $\ddagger$ & DMS010 ${ }^{\mathrm{T}}$ & 45.9 & 95 & $\begin{array}{l}\text { Boden et al. } \\
(2010)\end{array}$ \\
\hline
\end{tabular}

* Originally named 'Methylophaga murata'.

†Originally named 'Methylomonas thalassica'.

‡Originally named 'Methylophaga thiooxidans'.

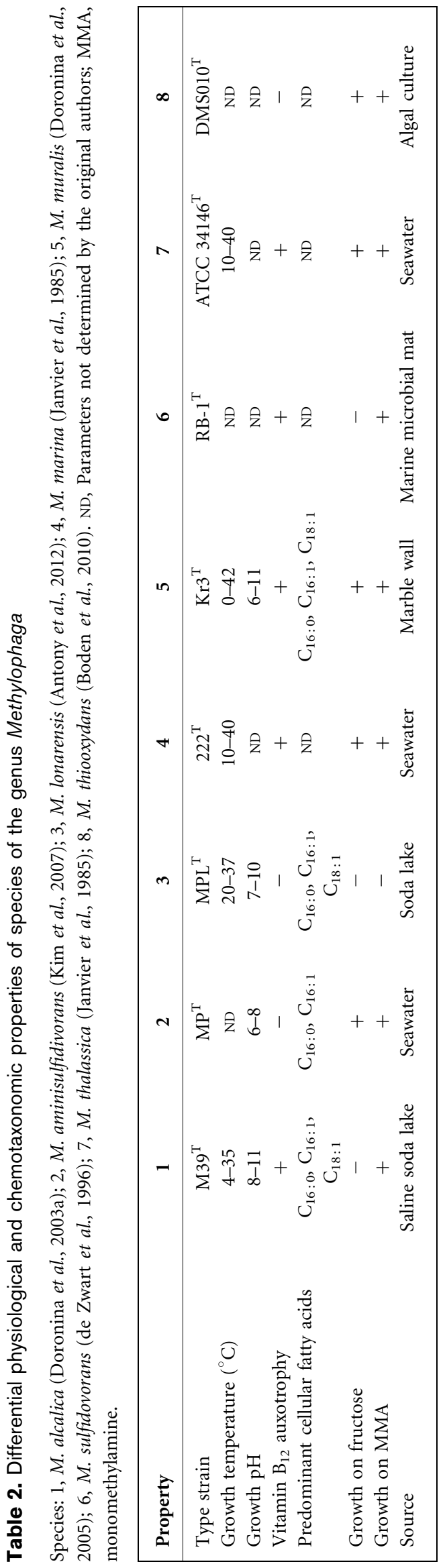




\section{Emended description of the genus Methylophaga Janvier et al. 1985}

This emended description is based on that of Janvier et al. (1985) with emendations based on de Zwart et al. (1996), Doronina et al. (2003a, 2005), Li et al. (2007), Kim et al. (2007), Boden et al. (2010) and Antony et al. (2012).

Cells are non-sporulating, Gram-negative rods, motile by means of a single polar flagellum. Thick periplasmic space of 20-30 nm. Strictly aerobic moderate halophile. Some species are alkaliphilic. Some species reduce nitrate to nitrite. Some strains are auxotrophic for vitamin $B_{12}$. The dominant respiratory quinone is UQ-8. Does not grow on complex media. Does not grow in the absence of $\mathrm{NaCl}$. Catalase- and oxidase-positive. One-carbon compounds are used as sole carbon and energy sources by all strains, with carbon assimilation proceeding via the KDPG-variant RuMP pathway. Does not grow on methane. Some species grow on a limited range of multicarbon compounds, namely fructose, substituted thiophenes or long-chain alkanesulfonates. Chemolithoheterotrophy is observed in some species. Autotrophic growth is not observed. DNA $\mathrm{G}+\mathrm{C}$ contents range from 42 to $50 \mathrm{~mol} \%$. Typically isolated from environments of low water activity, such as marine environments.

The type species is Methylophaga marina. Other species with validly published names are $M$. alcalica, $M$. aminisulfidivorans, M. lonarensis, M. muralis, M. sulfidovorans, M. thalassica and M. thiooxydans.

\section{Acknowledgements}

Professor Donovan P. Kelly is thanked for many stimulating discussions on taxonomy and systematics and Professor J. Colin Murrell is thanked for insightful comments on the manuscript. Chakkiath Paul Antony is thanked for allowing access to his previously unpublished manuscript on $M$. lonarensis sp. nov.

\section{References}

Antony, C. P., Doronina, N. V., Boden, R., Trotsenko, Y. A., Shouche, Y. S. \& Murrell, J. C. (2012). Methylophaga lonarensis sp. nov., a moderately haloalkaliphilic methylotroph isolated from the soda lake sediments of a meteorite impact crater. Int J Syst Evol Microbiol 62, 1613-1618.

Boden, R., Kelly, D. P., Murrell, J. C. \& Schäfer, H. (2010). Oxidation of dimethylsulfide to tetrathionate by Methylophaga thiooxidans sp. nov.: a new link in the sulfur cycle. Environ Microbiol 12, 2688-2699.
Boden, R., Kelly, D. P., Murrell, J. C. \& Schäfer, H. (2011). Methylophaga thiooxydans sp. nov. In List of New Names and New Combinations Previously Effectively, but not Validly, Published, Validation List no. 137. Int J Syst Evol Microbiol 61, 1-3.

Boden, R., Ferriera, S., Johnson, J., Kelly, D. P., Murrell, J. C. \& Schäfer, H. (2011). Draft genome sequence of the chemolithoheterotrophic, halophilic methylotroph Methylophaga thiooxydans DMS010. J Bacteriol 193, 3154-3155.

de Zwart, J. M. M., Nelisse, P. N. \& Kuenen, J. G. (1996). Isolation and characterization of Methylophaga sulfidovorans sp. nov.: an obligately methylotrophic, aerobic, dimethylsulfide oxidizing bacterium from a microbial mat. FEMS Microbiol Ecol 20, 261-270.

de Zwart, J. M. M., Nelisse, P. N. \& Kuenen, J. G. (1998). Methylophaga sulfidovorans sp. nov. In List of New Names and New Combinations Previously Effectively, but not Validly, Published, Validation List no. 67. Int J Syst Evol Microbiol 48, 1083-1084.

Doronina, N. V., Krauzova, V. I. \& Trotsenko, Yu. A. (1997). [Methylophaga limanica sp. nov.: a new species of moderately halophilic, aerobic, methylotrophic bacteria]. Mikrobiologiia 66, 520-526 (in Russian).

Doronina, N. V., Darmaeva, T. D. \& Trotsenko, Y. A. (2003a). Methylophaga alcalica sp. nov., a novel alkaliphilic and moderately halophilic, obligately methylotrophic bacterium from an East Mongolian saline soda lake. Int J Syst Evol Microbiol 53, 223-229.

Doronina, N., Darmaeva, T. \& Trotsenko, Y. (2003b). Methylophaga natronica sp. nov., a new alkaliphilic and moderately halophilic, restricted-facultatively methylotrophic bacterium from soda lake of the Southern Transbaikal region. Syst Appl Microbiol 26, 382389.

Doronina, N. V., Li, T. D., Ivanova, E. G. \& Trotsenko, Y. A. (2005). [Methylophaga murata sp. nov.: a haloalkaliphilic aerobic methylotroph from deteriorating marble]. Mikrobiologiia 74, 511-519 (in Russian)

Doronina, N. V., Li, T. D., Ivanova, E. G. \& Trotsenko, Y. A. (2011). Methylophaga muralis sp. nov. in list of new names and new combinations previously effectively, but not validly, published, validation list no. 138. Int J Syst Evol Microbiol 61, 475-476.

Han, G. H., Kim, W., Chun, J. \& Kim, S. W. (2011). Draft genome sequence of Methylophaga aminisulfidivorans MPT. J Bacteriol 193, 4265 .

Janvier, M., Frehel, C., Grimont, F. \& Gasser, F. (1985). Methylophaga marina gen. nov., sp. nov. and Methylophaga thalassica sp. nov., marine methylotrophs. Int J Syst Bacteriol 35, 131-139.

Kim, H. G., Doronina, N. V., Trotsenko, Y. A. \& Kim, S. W. (2007). Methylophaga aminisulfidivorans sp. nov., a restricted facultatively methylotrophic marine bacterium. Int J Syst Evol Microbiol 57, 20962101.

Li, Ts. D., Doronina, N. V., Ivanova, E. G. \& Trotsenko, lu. A. (2007). [Vitamin B12-independent strains of Methylophaga marina isolated from Red Sea algae]. Mikrobiologiia 76, 88-94 (English translation). 